Intentionality, numerical growth and the rural church

\title{
David Voas
}

University College London, London, England, UK

Author note:

Professor David Voas

Department of Social Science

UCL Institute of Education

University College London

Email: d.voas@ucl.ac.uk 


\begin{abstract}
A recent report on church growth argued that there are no strong connections between numerical growth and worship style or theological tradition. Instead, what seems crucial is that congregations engage in reflection: choices should be made intentionally, rather than by default. This article summarises the evidence for that claim and considers the implications for rural churches. To the extent that congregations are inward-looking, follow inherited practice and are resistant to change, it may be difficult to avoid stagnation and decline. The revitalisation of tradition is a challenge for rural clergy and congregations.
\end{abstract}

Keywords: Church of England, church growth, decline, churchmanship, tradition, reflection 


\section{The geography of Anglicanism}

There is a clear urban/rural divide in Anglican churchgoing, as can be seen by combining annual parish returns with data from the population census (made possible by the work of the Research and Statistics unit in the Church of England). In towns and cities across England, $2 \%$ of adults (aged 16+) will attend services in a parish church on a usual Sunday. In villages the corresponding figure is $4.5 \%$. The difference has two components: religion is comparatively stronger in the countryside than in the cities, and the Church of England has a larger share of the actively religious population in rural areas. Not only are cities home to many followers of non-Christian faiths, they also offer a large number of independent churches.

Institutional religion embodies tradition, and tradition is strongest in rural districts. People live in small, natural communities (as opposed to the virtual communities of friends scattered across a big city). They are likely to be in closer contact with their neighbours. Many have a connection with a particular church going back a few generations, and even those who do not may see it as a focal point for community activities. It is still common for children to be baptised, couples to have church weddings, and families to attend services at least occasionally. Times are changing everywhere, but the countryside remains a more favourable environment for religious participation, especially on special occasions, than the large towns.

The comparatively low attendance levels found in towns and cities are in part the legacy of urban decline that began many decades ago, though they are now potentially being reversed. Village churches have more participants relative to population, but they are often struggling to maintain their numbers. Elderly, rural, white congregations are important but becoming comparatively less so. Vitality is easier to find in areas with younger, urban, ethnic minority attenders. 
In a report for the Church of England on church growth, Voas and Watt (2014) suggested that deliberately choosing a style and theological orientation that is suited to the parish is more important that adopting any particular 'churchmanship'. This article summarises the case for that hypothesis and outlines the implications for the rural church, while making it clear how much evidence is still needed.

\section{The role of intentionality}

Over the past few years the Church of England has commissioned and debated research into the causes of church growth and decline. A widely quoted sound-bite was 'There is no single recipe for growth; there are no simple solutions to decline'. The road to growth depends on the context; what works in one place may not work in another. Growth is a product of good leadership (lay and ordained) working with a willing set of churchgoers in a favourable environment. That much is relatively uncontroversial.

Perhaps surprisingly, and as discussed further in the next section, there are no strong connections between growth and worship style, theological tradition, and so on. Less formal worship styles are indeed correlated with growth when viewed in isolation. Once other variables are taken into account, however, the findings are much less clear. Much of the apparent positive effect of contemporary worship may be attributable to other factors, for example the youth of the ordained minister.

What seems crucial is that congregations are constantly engaged in reflection; churches on autopilot tend to do poorly. The claim about the importance of intentional choices was repeated in the summaries distributed by the Church (for example the brochure entitled 'From Anecdote to Evidence', page 30). It is reasonable to ask whether the statement is well founded or mere conjecture. I believe that a via media is defensible: there are some tantalising clues, but ultimately it is a hypothesis that requires further testing. 
The hypothesis is not new, of course. One chapter of What Makes Churches Grow? by Bob Jackson, a leading expert on church growth, is entitled 'Intending to grow' (Jackson 2015: 73-91). It is largely devoted to Mission Action Plans, first devised in 1993 (Jackson 2005: 75-6). Formal planning is only one expression of intentionality, however; arguably the crucial quality is a desire to grow coupled with a willingness to reflect and change.

The data used in the present study come from a large online survey administered between April and July 2013 as part of the Church Growth Research Programme. The survey was designed to identify factors related to numerical change in Anglican church attendance. Invitations were sent by e-mail to ordained ministers - most with incumbent status - in a large sample of parishes. The first part of the survey was principally concerned with profiling the church in terms of size, worship style, activities and so on. The second part elicited information about the respondent's characteristics and personality. Responses were received from 1,703 churches; more detail regarding the sample and overall study can be found in Voas and Watt (2014).

\section{Quantitative evidence on style of worship}

Survey respondents were asked a number of questions about the frequency and style of worship at the church. They were asked to place the main Sunday service at a point along three scales: low to high church, non-liturgical to liturgical, and contemporary to traditional music. The first two of these were very highly correlated, and music was closely if not quite so strongly associated with those dimensions. Further questions asked: Over the course of a month, how much variation is there in the worship style of your main Sunday service? How much variety is there in the worship styles of the different services held in any given week (if applicable)? How much change in services and worship styles has there been in the past several years? 
Taken individually, the factors associated with 'objectively measured' (from annual parish returns) growth are non-liturgical worship, contemporary music, variety across the week, and change in recent years. In addition, variation from one Sunday to the next is linked to self-reported growth, as is low-church worship. The number of services (Sunday or midweek) appears not to be relevant to either measure of growth.

Analysing all of the factors at the same time, so that the effect of each is assessed while holding the others constant, the picture is somewhat different: see Table A1 in the Appendix. Once again the number of services has no effect, but variety and recent change are associated with self-reported growth, though not growth measured through parish statistics. The characteristics of the main Sunday service have effects on one or the other measure of growth, but not both. (For a fuller description of contrast between objectively measured and self-reported growth, see Voas \& Watt 2014: 5-8.) The results are rather mixed, so that both non-liturgical and high church worship appear to promote objectively measured growth. As suggested in the next paragraph, this apparent paradox may in fact provide a clue to what actually matters.

It should be noted that these associations are all rather weak (particularly with objectively measured growth, where these explanatory variables account for only $1.5 \%$ of the variance). Churches that place themselves at the very end of the 'high church' dimension are the most likely to be growing, closely followed by those at the non-liturgical end of the accompanying scale. Growth is coming at the extremes. It is least likely to be found in the middle of these scales, or perhaps more accurately in the 'middling to old-fashioned' range: somewhat high church, somewhat liturgical and with relatively traditional music, without being self-consciously at the limits. One might conjecture that this kind of worship is symptomatic of stagnation rather than being the direct cause of decline. 
The hypothesis offered here is that vitality comes with reflection and choice; the particular style is less important than the fact that it has been considered and chosen, rather than adopted by default. And therein lies a challenge for most rural churches, which tend to be traditional and disinclined to go too far in embracing either high church or contemporary worship.

The survey provided some further evidence that church growth may be more closely associated with deliberate intentions than theological orientation (or 'churchmanship').

Clergy were asked to place themselves along three seven-point scales, running from Catholic to Evangelical, from Liberal to Conservative, and from Charismatic to non-Charismatic.

Controlling for other characteristics, churchmanship rarely shows any relationship to church growth (see Voas \& Watt 2014, Section 6, for more details). Ministers were also asked 'Which of these three church objectives is your priority? Numerical growth, Spiritual growth/discipleship, Social transformation'. Numerical growth was only the priority for $13 \%$ of respondents, but it is significantly associated with growth.

This finding may be influenced by post hoc rationalisation. One must suspect that clergy at growing churches are inclined to emphasize the importance of growth, while clergy in less favoured parishes will be more comfortable with the idea that discipleship or social action is the priority. Nevertheless the evidence is at least consistent with the notion that plans matter.

\section{Qualitative evidence on style of worship}

The suggested role of intentionality is consistent with the written comments on the survey. While worship style was one of the most frequently cited reasons for growth, there was no real consensus over what style was best. Changes to services - that is, innovation was often claimed to be what helped to produce growth. 
Many respondents did attribute their success to informality in worship, using terms such as relaxed, easy going, lively, open, friendly, flexible, or even 'a light-hearted approach to worship'. This type of service is thought to be especially suitable for people who are not usual attenders; one vicar referred to 'A more relaxed worship style that makes them feel welcome and comfortable'.

A related theme was 'accessibility', which is viewed by many as important for retaining visitors. Here the descriptions included accessible, seeker-friendly, user-friendly, and simplicity; ministers were 'always aware there might be visitors to service' and tried to provide 'preaching and teaching that connects with the unchurched'. If the quality of the preaching is high, people will enjoy it and come back. Being clear, engaging and addressing issues that people actually face were mentioned.

Accessibility was often regarded as implying less formal and more contemporary services, and definitely not those based on the 'impenetrable Prayer Book'. This view was not universally held, however. In a characteristically Anglican compromise, many respondents said that they adopted a relaxed or informal approach within traditional services. Here the lack of formality was in the way the service was conducted rather than in the content of the worship. Typical comments included:

Relaxed style though still with the formality of the liturgy.

We offer a traditional style of worship with a contemporary mix.

We have worked hard to liven up the liturgy such as the setting for the Mass whilst maintaining a traditional Catholic ethos.

Advocates of contemporary worship wrote about simplifying the liturgy, offering 'short and punchy' services, and 'shifting the emphasis of our music from Radio 3-style to Radio 2-style'. The aim is to produce 'vibrant worship' that is accessible. By contrast, some 
respondents asserted that it was the traditional nature of their services that made them popular.

We have picked up a number of Roman Catholics who are dissatisfied with trendy services in their former churches.

Traditionally the high church liturgy has attracted an eclectic congregation as we are really the only church representing this tradition in this part of the diocese, consequently we tend to attract those looking for this style of worship.

The church offers a liturgically-based traditional style of worship which is not common in our region ... and provides a warm welcome.

No single style of worship is popular with everyone, nor is it clear that contemporary worship always has an advantage in producing growth. Many churches deal with the problem of varied tastes by offering different types of service, with some attributing their growth to this variety.

We have four Anglican churches which offer distinctive styles of worship and we believe we offer something separate for those who prefer a service which balances sacraments, teaching and music.

Wider variety of services means more choice for people.

There has been significant growth as a result of offering a wider variety of worship on different days and at different times. We now have five different services with some overlapping attendance which whilst not huge in terms of numbers do bring in quite distinct congregations. 
The growth in these three churches is due to diversity and a willingness to change by the growth of and development of Cafe Church monthly as well as Traditional Evensong.

Being able to provide two distinctive styles of worship every Sunday so that people attend church and know the type of service they are coming to. (Definitely a sung communion with traditional hymns or informal service with contemporary music and coffee).

We are developing a suite of services focusing on particular Homogeneous Units. That way, people can pick and choose which church they want to belong to.

Many churches are trying to enhance the social aspect of services, sometimes through elaborating the traditional route of tea and coffee into breakfast or lunch before or after the service, and sometimes through 'café church' worship.

To reiterate the original point, the relative success (to the extent that it exists) of less liturgical worship seems to result not so much from the particular style as the fact that it was chosen rather than inherited. Decline may come about because of what one minister described as 'a degree of stagnation in the approach, variety, vitality and inclusiveness of our worship.' Traditional translates into unimaginative. Sometimes the service becomes more important than the ultimate end, with one respondent mentioning "poor leadership that refused children/youth access to worship.' By contrast, successful churches described 'a 'let's give it a go' mentality. We try different initiatives as experiments. If they work we invest in them, if they don't we drop them. Examples: 'Sunday Night Live', live secular entertainment in Costa Coffee with a short non-cringey 5-minute message.

\section{Lay attitudes to stability and change}


For there to be growth, the existing congregation must be willing to experience change. At a minimum the arrival of new people disrupts what might be a cosy club. In all probability there will need to be larger changes, in the timing and type of worship, in how and when the building is used, and crucially in shifting lay leadership towards younger and more recent members. Such changes are uncomfortable. It would be unfair to suggest that resistance to change is a rural phenomenon, but the relative stability of village communities may exacerbate the problem.

Many survey respondents mentioned unwillingness to change as a reason for church decline. Elderly congregations can be inward-looking and resistant to change. Even a change in incumbent can be upsetting. Long-time attenders may be reluctant to try new forms of worship. Many village churches are seen as traditional and wanting to stay that way, with little to make them distinctive. One vicar linked the problem of generational replacement to these obstacles: decline results from 'Members ageing and dying, not replaced by younger ones. Younger people do occasionally come, but don't become permanent - probably because they can't identify socially with the generally elderly congregation. Most of the regulars are very warmly welcoming to newcomers, but they nevertheless expect them to fit in with existing patterns, because they themselves don't take kindly to radical change. It is frustratingly difficult to initiate anything new or different.'

A recurring theme is that established congregations are interested in social reproduction - that is, continuation or growth without change.

The majority still want to attend a communion service once a month or every week and they are content. They work only to ensure the church will still be here for them, they are not wanting to grow or change. They actually don't want new young people.

The church does want to grow, but only if the new people keep everything the same, behave in an 'appropriate' manner, are from 'nice' families, etc. etc. 
This church seems to have had little teaching about the faith for some time. I do the work, most are quite happy to sit in the pews. ... There has been a realisation that they need new people if the church is to survive, but for most that is 'new but on their terms'.

There is a welcoming culture in the congregation, but when newbies come they want them to fit in. It's as if they're saying 'this is how we do church, you are very welcome but this is how it is.' There is a big resistance to change.

Lay leadership may be weak or worse. In some ageing congregations there are fewer and fewer people to serve; faithful members, weekly attenders who were willing to volunteer, are dying or becoming infirm. Younger members often attend less often and are less willing or able to volunteer because of other commitments.

Some of the written comments are hair-raising:

The church was in decline and has not changed much. No willing adult to support the work with children, no Sunday school, no change allowed to service. The choir refuse to attend evening or all age worship and don't like contemporary stuff. PCC same people year after year. Apathetic uninvolved congregation want to come be fed go home and forget church till next week. Very few willing and even fewer able to work for growth.

I have come to a beleaguered churchy group which has no prayer, no Bible study, no expectation of God speaking to them, no children's work other than family services, no visiting of members, and rigidity in worship style. ... many have no experience of the Holy Spirit and no real commitment to Christ.

It's like trying to do palliative care, midwifery and in-vitro fertilisation on the same ward. Congregation elderly and dying. I do a Fun@4 service once a month, and this is 
starting to build up at last. Can't call it Messy Church, as we don't have enough people to run it as Messy Church. We have one churchwarden who gets flummoxed if you ask her to photocopy the notice sheet. I have to put out the bins, count the money, do the accounts, photocopy the notice sheet - because there isn't anyone else to do them! I would love to delegate. I would love a ministry team, but there isn't anyone. At present all the PCC is indisposed: broken leg, broken wrist, pacemaker, psych care. Just me and the churchwarden are reasonably fit and she has MS.

This has actually been an extremely difficult parish to minister in. I could write essays about the difficulties that the headstrong laity have caused both in and out of the church. ... The diocese and deanery have been totally supportive but one of our great Anglican problems is that too much power can be vested in indolent and obnoxious laity.... The great joys in this parish and, in fact, the great demonstrations of Christian faith in this parish are found outside of the small number who have called themselves 'church' here.

\section{The geographical distribution of church growth}

Levels of Church of England attendance are highest in rural parishes where the population is predominantly Christian and white British, with older people well represented. For growth, however, it is a different story. Unsurprisingly, population growth is linked to increased church attendance, just as rises in the percentage of the people identifying with no religion on the census are associated with decline. Areas with substantial Christian ethnic minority populations - which of course tend to be urban - are most likely to see church growth. Higher education is also associated with growth. (See Table A2 in the Appendix.)

It should be noted, though, that these factors account for only a very small fraction of the overall variation in church growth. (The model described in Table A2 explains only 2\% 
of the variance.) Demographic change makes a difference, but it is not remotely necessary or sufficient for growth to occur.

Based on measures of attendance from the annual parish returns, there seems to be no difference between churches in rural and urban areas in the relative frequency of growth and decline. (The amount of growth is 'standardised', or expressed as a number of standard deviations in the attendance counts. This procedure makes change comparable across parishes of different sizes and also across different measures of attendance. Further details can be found in Appendix 2 of Voas \& Watt 2014.) The figures show a very slight tendency for rural churches to be stable rather than declining, but the contrast is not statistically significant (Table 1). By contrast, urban churches are more likely to claim that they have grown substantially, and on this 'subjective' measure the difference is significant (Table 2). - insert tables1 and 2 about here -

\section{The impact of geographical mobility}

At a local level, people moving into an area can make a difference. New housing will bring in new people, some of whom will transfer from other churches. The arrival of retired people or Christian immigrants can be a boost to growth. In most of these cases, of course, the growth is not produced by making new Christians but through drawing in existing ones.

Demography is more frequently mentioned as a cause of decline. Young people move out of parishes where houses are expensive or from rural areas where there is little work. Where many houses in a parish are holiday homes, attendance will be affected. In very small parishes there are few new people available to attract in any case.

Some problems are especially acute in cities. In some instances elderly members of the congregation tend to retire out of the area. Populations are relatively mobile, with the result that people do not stay long enough to develop enduring ties in the local church. And of 
course the growth of non-Christian minority groups may mean that the pool of Christians is smaller. In some instances the composition of a parish has changed significantly. Growth in the number of new immigrants from a Christian background can provide a boost, but some of the new attenders move away from relatively deprived areas as soon as they are able to do so.

Merging churches will boost the numbers meeting in one building, which in itself does not constitute real growth; indeed, net losses are common, as some members stop attending if their church is closed. In some instances, however, the process may lead to genuine growth. One vicar wrote that their growth was explained by:

A graft from HTB to serve the evening service. We had tried a contemporary service once a month but it never grew beyond 30. A decision was taken to seek a graft onto that service and grow it. It started with an aggregate of 60 and has grown to 200 in six months. Young adults realised they didn't have to commute into London churches and want to worship in a smaller church in which they are known and in which they can serve. A delight.

\section{The policy conundrum}

Numerical growth must be distinguished from the level of participation, and the socio-demographic context is important to both. Often attendance is highest as a proportion of the population in rural areas where growth is hard to achieve; growing churches are often found in cities where relatively few people are active Anglicans. Middle class suburbs with church schools, or inner city parishes with Christians arriving from overseas, offer great opportunities; rural districts and areas of industrial decline can be far more challenging. One of the difficulties for the Church of England is that its traditional rural strongholds and its new centres of urban growth are so different.

In addition, the ethnic composition of the laity is changing rapidly, while the clergy is still largely old and white (if increasingly female). The Church is faced with a strategic 
challenge: the question is whether the focus should be on supporting areas of existing strength or on developing churches that are growing but not yet as significant in absolute terms.

In towns and cities that have experienced economic decline, the church may have more potential for mission but its ties to the local population are often disintegrating. Christians from overseas are revitalising many urban congregations; for them religious participation is a normal part of life, and the main challenge for the Church of England is marshalling that energy rather than losing it to independent churches. Church is often strong in suburban areas where civic engagement is valued, young families produce and consume worthwhile activities for their children, and there is still a cultural link to Christianity. Churches are well embedded in rural communities, but they are often numerically weak and financially struggling.

All of these statements describe tendencies; there will be many exceptions at a local level. It is helpful to classify areas on two dimensions: the proportion of the population that is Anglican and the change in church participation. Business consultants label the result a growth-share matrix (The Economist 2009).

High share

Good growth potential Middle class suburbs

Poor recent growth
Rural villages

\section{Low share}

Urban areas with many Christian immigrants

Towns and cities with struggling white British populations

The traditional recommendation would be to focus on the 'stars' and to wind down poorly performing sectors. The church - not to say Christian - context is different. 
Nevertheless it is helpful to think about the different strategies that are appropriate in each type of area.

For example, offering a suite of services is only viable if one has the numbers to fill them. Churches in rural parishes would struggle to offer such a variety and are left to deal with a 'one size must fit all' mentality. Is it then the case that while in urban parishes church attendance can be more about choosing (and consuming) a specific type of worship, in rural parishes church has to be about something else (such as community)? The challenge for collective reflection may be not so much about the nature of worship as the purpose of the church. 


\section{References}

Jackson, B. (2005). The road to growth: Towards a thriving Church. London: Church House Publishing.

Jackson, B. (2015). What makes churches grow? Vision and practice in effective mission. London: Church House Publishing.

The Economist (2009). Growth share matrix. http://www.economist.com/node/14299055 Voas, D., \& Watt, L. (2014). Numerical change in church attendance: National, local and individual factors. (Revised and expanded edition, September 2014). London: Church of England. 


\section{Notes on Contributor}

Professor David Voas is Professor of Social Science and Head of the Department of Social Science at the UCL Institute of Education, London, UK

Address for correspondence: David Voas, Head of Department of Social Science, University College London, Gower Street, London WC1E 6BT. Email: d.voas@ucl.ac.uk 
Table 1

Area type and growth (objectively measured) \%

\begin{tabular}{lccccccc}
\hline & \multicolumn{6}{c}{ Standardised change } \\
\cline { 2 - 7 } & $<-1$ & -1 to -.5 & -.5 to 0 & 0 to .5 & .5 to 1 & $>1$ \\
\hline Rural/village & 15 & 19 & 23 & 17 & 9 & 17 \\
Town/city & 18 & 21 & 21 & 14 & 10 & 16 \\
\hline
\end{tabular}

Note: $\quad \mathrm{N}=1,744$ 
Table 2

Area type and growth (self-reported) \%

\begin{tabular}{lccccc}
\hline & $\begin{array}{c}\text { Declined } \\
\text { substantially }\end{array}$ & $\begin{array}{c}\text { Declined } \\
\text { a little }\end{array}$ & $\begin{array}{c}\text { Stayed about } \\
\text { the same }\end{array}$ & $\begin{array}{c}\text { Grown } \\
\text { a little }\end{array}$ & $\begin{array}{c}\text { Grown } \\
\text { substantially }\end{array}$ \\
\hline Rural/village & 7 & 20 & 21 & 39 & 13 \\
Town/city & 5 & 20 & 17 & 39 & 19 \\
\hline
\end{tabular}

Note: $\quad \mathrm{N}=1,605$ 


\section{Appendix}

Table A1

Worship service characteristics associated with church growth: regression coefficients

\begin{tabular}{|c|c|c|c|c|c|c|c|c|}
\hline & \multicolumn{4}{|c|}{ Objectively measured growth } & \multicolumn{4}{|c|}{ Self-reported growth } \\
\hline & B & $\begin{array}{l}\text { Std. } \\
\text { error }\end{array}$ & Beta & Sig. & B & $\begin{array}{l}\text { Std. } \\
\text { error }\end{array}$ & Beta & Sig. \\
\hline (Constant) & .198 & .162 & & .222 & .063 & .157 & & .689 \\
\hline Number of Sunday services & .000 & .012 & .001 & .975 & -.004 & .011 & -.010 & .708 \\
\hline Number of midweek services & .012 & .010 & .036 & .242 & .012 & .010 & .036 & .232 \\
\hline \multicolumn{9}{|l|}{ Worship style of largest Sunday service } \\
\hline Low church to high church & .059 & .030 & .087 & .052 & .031 & .029 & .046 & .297 \\
\hline Non-liturgical to liturgical & -.076 & .029 & -.117 & .008 & -.043 & .028 & -.067 & .120 \\
\hline Contemporary music to traditional music & -.034 & .025 & -.051 & .175 & -.060 & .024 & -.092 & .013 \\
\hline Variation over a month (none to a lot) & -.051 & .022 & -.071 & .020 & -.021 & .022 & -.030 & .321 \\
\hline Variety in worship styles in any given week & .021 & .019 & .035 & .262 & .056 & .018 & .093 & .003 \\
\hline $\begin{array}{l}\text { Change in services and worship styles in recent } \\
\text { years (none to substantial) }\end{array}$ & .032 & .022 & .046 & .136 & .147 & .021 & .212 & .000 \\
\hline
\end{tabular}

Note: Negative coefficients indicate that the effect is negative, controlling for all of the other variables. 
Table A2

2011 census variables affecting objectively measured church growth: regression coefficients and significance

\begin{tabular}{lcccc}
\hline & B & Std. error & Beta & Sig. \\
\hline (Constant) & -.247 & .111 & & .026 \\
& & & & \\
Proportion with higher education $^{*}$ & .009 & .003 & .090 & .001 \\
Ethnic minority proportion, non-Christians excluded $^{*}$ & .010 & .003 & .097 & .001 \\
Rural-urban scale & -.023 & .012 & -.051 & .066 \\
\hline
\end{tabular}

*Variables with statistically significant effects.

Note: Negative coefficients indicate that the effect is negative, controlling for all of the other variables. 